Crop Breeding and Applied Biotechnology 15: 66-71, 2015

Brazilian Society of Plant Breeding. Printed in Brazil

\title{
ARTICLE
}

http://dx.doi.org/10.1590/1984-70332015v15n2a13

\section{Effects of immersion system and gibberellic acid on the growth and acclimatization of micropropagated pineapple}

Ramon Felipe Scherer ${ }^{1}$, Daniel Ferreira Holderbaum ${ }^{1}$, Antônio Corrrêa Garcia ${ }^{1}$, Dorival Almeida da Silva ${ }^{1}$, Douglas André Steinmacher ${ }^{1}$ and Miguel Pedro Guerra ${ }^{1 *}$

Received 26 February 2014

Accepted 12 November 2014

\begin{abstract}
Micropropagation based techniques enable the mass production of pest-and disease-free stock plants. Aiming at optimizing pineapple [Ananas comosus (L.) Merril] micropropagation, a complete randomized experiment with three factors was established: immersion system (2 L twin flasks temporary immersion and permanent immersion); culture medium (supplemented or not with GA ); and shoot height class. The effects on regeneration rate (number of new shoots per $1 \mathrm{~g}$ fresh mass (FM) of inoculated microshoots), FM per shoot, and shoot survival were evaluated. Significant interactions $(p<0.05)$ were observed in the regeneration rate, and simple effects $(p<0.05)$ were detected for FM per shoot. All treatments resulted in a survival rate higher than $95 \%$. Altogether, it was found that $2 \mathrm{~L}$ twin flasks temporary immersion and MS culture medium free of GA allowed the optimization of the protocol used. This treatment was tested with positive response in a biofactory system that uses sterile plastic bottles $(5 \mathrm{~L})$.
\end{abstract}

Keywords: Micropropagation, regeneration rate, biofactory.

\section{INTRODUCTION}

Pineapple (Ananas comosus var. comosus) was domesticated in northern South America from the wild species A. comosus var. ananassoides (Clement et al. 2010), and currently it is one of the major tropical fruits on the global market (FAOSTAT 2011). It is estimated that $2 / 3$ of the global pineapple production is consumed as fresh fruit and $1 / 3$ as processed fruit (Reinhardt and Rodriguez 2009). The use of low quality propagules, which transmit pests and diseases, is one of the major constraints of its cultivation (Be and Debergh 2006). Micropropagation protocols for pineapples based on conventional organogenesis have been employed for the large-scale production of clonal seedlings with high genetic and sanitary standards (Dal Vesco et al. 2001). However, micropropagated plantlets are more expensive as compared to those produced by the conventional method based on the use of tops, slips and suckers (Teixeira et al. 2001, Be and Debergh 2006). Recently, new micropropagation protocols based on nodular cluster cultures (NC) demonstrated high regenerative efficiency in Bromeliaceae species (Guerra and Dal Vesco 2010), such as Vrisea reitzii (Dal Vesco and Guerra 2010), Billbergia zebrina (Dal Vesco et al. 2011), and pineapple (Scherer et al. 2013). Nodular cluster cultures are globular organogenic nodule groups composed of meristematic clusters of yellow-greenish to translucent coloration, with friable to slightly compact texture (Dal Vesco and Guerra 2010). Based on such approaches, Scherer et al. (2013) developed a new protocol for pineapple micropropagation based on $\mathrm{NC}$, where temporary immersion systems (TIS) were used for the NC multiplication, and further $\mathrm{NC}$ differentiation into microshoots, defined as shoots smaller than $0.5 \mathrm{~cm}$. However, it should be noted that only a permanent immersion system (PIS), in combination with different levels of gibberellic acid $\left(\mathrm{GA}_{3}\right)$, was used during the shoot growth phase in the work of Scherer et al. (2013).

The use of temporary immersion systems results in increased multiplication rates and less handling and labor; thus, allowing the reduction of production costs (Feuser et al. 2003, Rech Filho et al. 2005, Steinmacher et al. 2011). Escalona et al. (1999) developed the twin flasks temporary immersion system (TIS-TF) for pineapple micropropagation and, later, other studies reported the efficiency of this system in many other plant species (Etienne and Berthouly 2002, Rech Filho et al. 2005, Niemenak et al. 2008, Steinmacher et al. 2011). Furthermore, the use of TIS resulted in a lower

${ }^{1}$ Universidade Federal de Santa Catarina (UFSC), Rod. Admar Gonzaga, km 3, 88.034-001, Florianópolis, SC, Brazil. *E-mail: miguel.guerra@ufsc.br 
rate of somaclonal variation for pineapples, as compared to the permanent immersion system (Feuser et al. 2003).

Gibberellins (GA) are a large group of plant hormone produced by tetracyclic diterpenoid carboxylic acids, with more than a hundred representatives. Three of them, $\mathrm{GA}_{1}$, $\mathrm{GA}_{3}$ and $\mathrm{GA}_{4}$, are the most abundant in higher plants. They are involved in different plant biological processes, such as germination, reproduction, and cell elongation, among others (Hedden and Thomas 2012, Girek et al. 2013, Rastogi et al. 2013). Bromeliad micropropagation protocols based on organogenesis usually employ $\mathrm{GA}_{3}$ to promote shoot elongation (Escalona et al. 1999, Dal Vesco and Guerra 2010, Dal Vesco et al. 2011, Scherer et al. 2013). However, only a few reports have described the effects of this compound on pineapple micropropagation.

Therefore, the present work aimed to optimize the pineapple micropropagation protocol based on $\mathrm{NC}$ cultures developed by Scherer et al. (2013), by evaluating the effects of TIS, combined or not with $\mathrm{GA}_{3}$ and further evaluating such effects on the acclimatization phase.

\section{MATERIAL AND METHODS}

\section{In vitro phase}

The experiments were carried out at the Plant Developmental Physiology and Genetics Laboratory of the Federal University of Santa Catarina, Brazil. Microshoots cultured in RITA ${ }^{\circledR}$ temporary immersion system, as described by Scherer et al. (2013), were used as starting cultures (Figure 1A). Basal culture medium was based on the MS saline formulation (Murashige and Skoog 1962) supplemented with $30 \mathrm{~g} \mathrm{~L}^{-1}$ sucrose and Morel vitamins (Morel and Wetmore 1951) (hereinafter termed MSB). The $\mathrm{pH}$ of the culture medium was adjusted to 5.5 before autoclaving at $1.1 \mathrm{~atm}$ and $121{ }^{\circ} \mathrm{C}$ for $20 \mathrm{~min}$. The experiment had a completely randomized block design, with three factors: 1) immersion system ( $2 \mathrm{~L}$ twin flasks temporary immersion (TIS-TF) and permanent immersion in glass flasks (69 mm x $121.7 \mathrm{~mm} / 350 \mathrm{~mL}$ ) (PIS)); 2) culture medium (MSB only and MSB supplemented with $\mathrm{GA}_{3}$ at $10 \mu \mathrm{M}$ ); and 3) shoot height class $(2-3 \mathrm{~cm}, 3-4 \mathrm{~cm}, 4-5 \mathrm{~cm}, 5-6$ $\mathrm{cm}, 6-7 \mathrm{~cm}$, and higher than $7 \mathrm{~cm}$ ). The experiment had four replicates. The ratio of $30 \mathrm{~mL}$ of culture medium for each $0.5 \mathrm{~g}$ fresh mass (FM) of microshoots was used in all experimental units. The experimental unit of treatments in TIS-TF consisted of twin flasks inoculated with $5 \mathrm{~g}$ FM of microshoots. For treatments in PIS, the experimental unit consisted of 5 glass flasks, each one inoculated with 0.5 g FM of microshoots. For inoculation, microshoots were
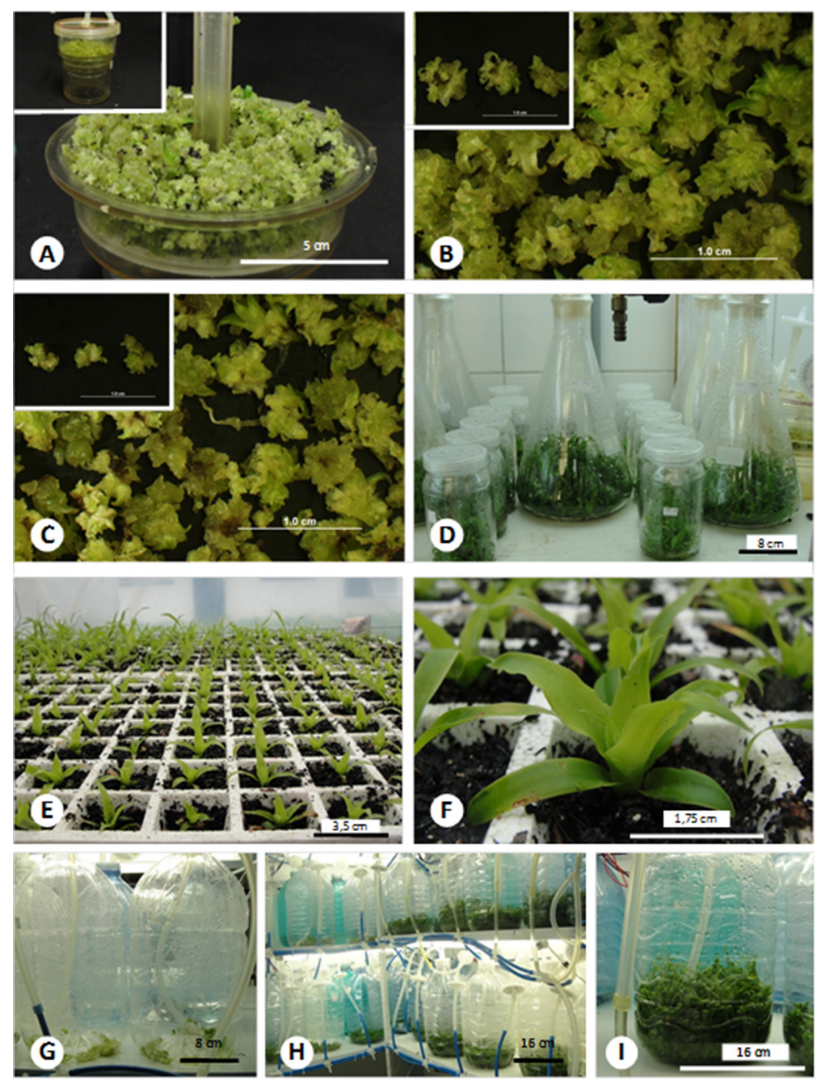

Figure 1. In vitro development of pineapple shoots and acclimatization. A - Microshoots developed in RITA ${ }^{\circledR}$ temporary immersion system; B - Microshoots before sectioning for inoculation; C - Microshoots after sectioning for inoculation; D - Shoots produced in the permanent immersion system and in the temporary immersion system; E and F - Plantlets after 60 days of acclimatization; G, H and I - Biofactory system for mass production of plantlets using sterile plastic bottles $(5 \mathrm{~L})$.

sectioned to form clusters with approximately $0.5 \mathrm{~cm}$ in diameter (Figure 1B and 1C, respectively). In the TIS-TF culture, the immersion cycle consisted of 3 min every $3 \mathrm{~h}$. After 8 weeks, the regeneration rate (number of new shoots per $1 \mathrm{~g}$ FM of microshoots) and FM per shoot were evaluated, and data were analyzed by ANOVA. Normal distribution of residuals and homoscedasticity were checked by graphical exploratory analysis (QQ-Plots, scatter plots and plots of residuals by treatments). The regeneration rate showed the appropriateness of the linear model assumptions. The BoxCox transformation (Box and Cox 1964) was employed to normalize the distribution of residuals of data from FM per shoot, and in this case the estimated means were reported after back-transformation. When significant effects were found, treatment means were compared by the SNK test, considering $95 \%$ confidence.

\section{Acclimatization phase}


In the acclimatization phase, shoots were placed in trays of 128 cells containing a mixture $(1: 1)$ of carbonized rice hull and the commercial substrate Tropstrato ${ }^{\circledR}$ forestry. Shoots longer than $2 \mathrm{~cm}$ were used, derived from the four treatments: MSB medium in TIS-TF ( $\mathrm{n}=96$ shoots); MSB $+\mathrm{GA}_{3}(10 \mu \mathrm{M})$ in TIS-TF $(\mathrm{n}=160$ shoots $)$; MSB in PIS $\left(\mathrm{n}=176\right.$ shoots), and MSB $+\mathrm{GA}_{3}(10 \mu \mathrm{M})$ in PIS $(\mathrm{n}=64$ shoots). Plantlet survival was assessed 60 days after transfer to the acclimatization greenhouse using the $\chi^{2}$ test for a $4 \times 2$ contingency table.

\section{RESULTS AND DISCUSSION}

\section{In vitro phase: shoot regeneration}

For the regeneration rate, all double interactions were significant $(p<0.05)$ (immersion system vs. culture medium; immersion system vs. shoot height class; culture medium vs. shoot height class), and no triple interaction was observed $(p>0.05)$. The regeneration rate obtained on the two immersion systems was dependent on the shoot height class (Figure 2). In the smaller shoot height classes $(2-3 \mathrm{~cm}$ and 3-4 cm), the highest number of shoots was found in PIS. In the intermediate class $(4-5 \mathrm{~cm})$, the two immersion systems produced no significant difference in regeneration rate. However, in the classes with longest shoots $(5-6 \mathrm{~cm}$, 6-7 cm, and higher than $7 \mathrm{~cm}$ ), a higher regeneration was observed in TIS-TF. Similar results indicating the superiority of TIS for the production of shoots and plantlets with larger size were observed in peach palm (Steinmacher et al. 2011), eucalyptus (McAlister et al. 2005, Oliveira et al.

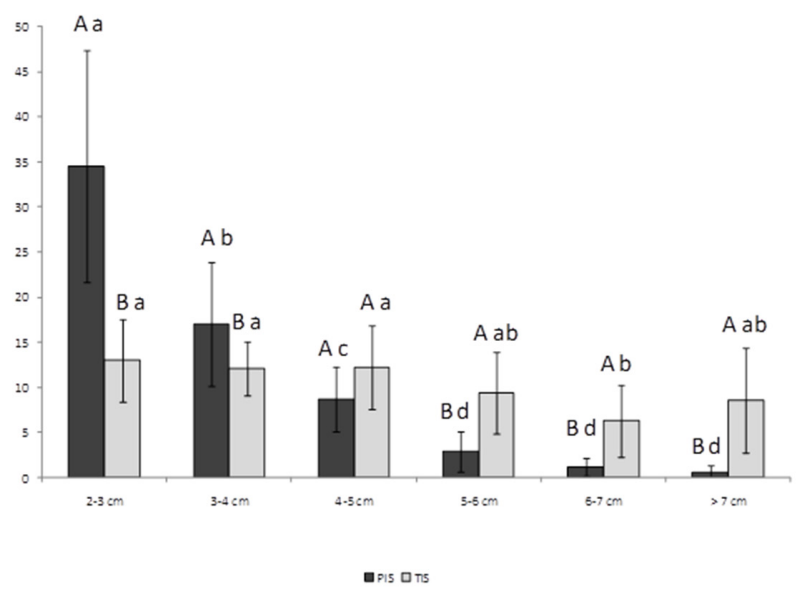

Figure 2. Effect of permanent and temporary immersion systems on the regeneration rate (mean \pm standard deviation) of pineapple shoots in different classes of shoot height. Means followed by different letters, uppercase between immersion systems and lowercase inside each immersion system, are different according to SNK test at $95 \%$ confidence. PIS: Permanent immersion system; TIS: Temporary immersion system.
2011), strawberry (Hanhineva et al. 2005), Spanish red cedar (Peña-Ramíres et al. 2010), lemon grass (Quiala et al. 2006), sugarcane (Lorenzo et al. 1998) and rubber tree (Etienne et al. 1997). It was also observed that TIS-TF resulted in greater stability in the regeneration rate between different classes of shoot height. In TIS-TF, no significant differences were noted between five of the classes of shoot height, as all of them maintained a high level of shoot production. In PIS, a marked concentration of shoots with smaller size and a significantly lower production of larger shoots were observed. These results are similar to those reported in peach palm (Steinmacher et al. 2011) and Spanish red cedar (Peña-Ramíres et al. 2010).

It has been suggested that TIS-TF provides enhanced and homogeneous responses in in vitro regeneration as a consequence of 1) shorter time of contact between culture medium and the cultures and more uniform distribution of nutrients and 2) air renovation. Such features enhance culture development by decreased hypoxia, less accumulation of harmful compounds, as observed by Steimacher et al. (2011) and Scherer et al. (2013), and better cell nutrition. It has also been suggested that TIS-TF provides an environment which allows higher shoot density and, consequently, higher vertical growth of shoots.

The regeneration rate was also affected by the combination of the culture medium composition and the shoot height class (Figure 3). MSB medium free of $\mathrm{GA}_{3}$ resulted in a higher regeneration rate of small shoots $(2-3 \mathrm{~cm}$ and $3-4 \mathrm{~cm}$ ) while no differences in the regeneration rate were

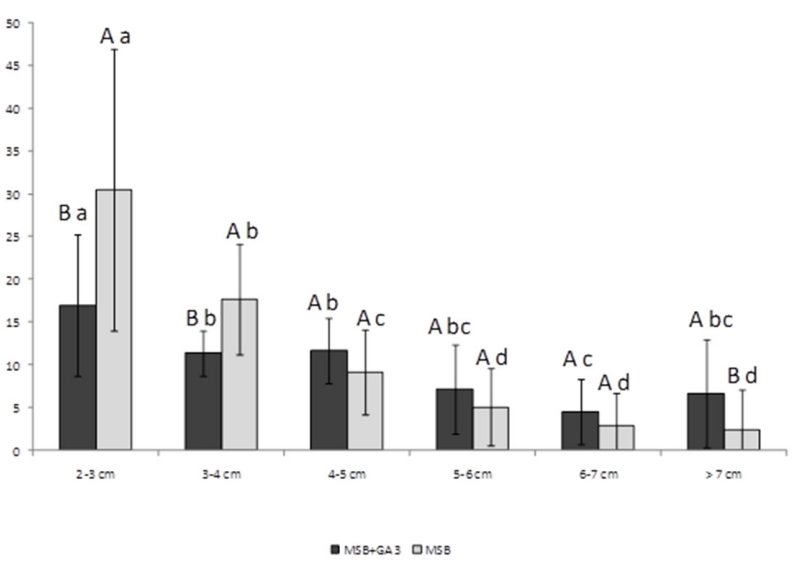

Figure 3. Effect of culture medium (MSB only or MSB supplemented with $\mathrm{GA}_{3}(10 \mu \mathrm{M})$ ) on the regeneration rate (mean \pm standard deviation) of pineapple shoots in different classes of shoot height. Means followed by different letters, uppercase between culture media and lowercase inside each culture medium, are different according to SNK test at $95 \%$ confidence. 
found between culture media in classes of shoot height ranging from $4-5 \mathrm{~cm}, 5-6 \mathrm{~cm}$ and 6-7 $\mathrm{cm}$. However, in class of shoots higher than $7 \mathrm{~cm}$ MSB supplemented with $\mathrm{GA}_{3}(10 \mu \mathrm{M})$ showed the highest regeneration rate. The supplementation of $\mathrm{GA}_{3}$ to MSB also provided more stability in the number of shoots among the classes of shoot height, resulting in more synchronous shoot development. In cultures of bromeliad species based on $\mathrm{NC}$, both shoot regeneration and synchronism in shoot development were positively affected by the presence of $\mathrm{GA}_{3}$ in the culture medium (Dal Vesco and Guerra 2010, Dal Vesco et al. 2011, Scherer et al. 2013), and the same was reported in other cultures (Dronne et al. 1999, Peña-Ramírez et al. 2010).

The interaction between immersion system and culture medium (Table 1) showed that the addition of $\mathrm{GA}_{3}$ to MSB was detrimental to the regeneration rate in PIS, while in TIS-TF no difference related to $\mathrm{GA}_{3}$ supplementation was observed. Interestingly, in PIS, the standard deviation of the regeneration rate was much higher than in TIS-TF, attesting to the more homogeneous regenerative performance in TIS.

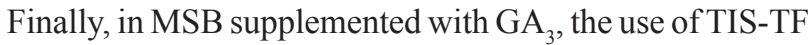
resulted in the highest regeneration rate, while in MSB free of $\mathrm{GA}_{3}$ the use of PIS showed the highest regeneration rate. It should be emphasized, however, that TIS-TF showed an overall higher synchrony of shoot production.

\section{In vitro phase: fresh mass per shoot}

In evaluating FM per shoot, simple effects were detected for the three factors $(\mathrm{p}<0.05)$, but no significant interactions were detected among them. Shoots developed in PIS had higher FM than shoots in TIS-TF (0.175 and $0.112 \mathrm{~g}$, respectively). Moreover, shoots produced in MSB free of $\mathrm{GA}_{3}$ were heavier than those obtained in MSB supplemented with $\mathrm{GA}_{3}(0.178$ and $0.111 \mathrm{~g}$, respectively), and a steady increase in the FM per shoot resulted from the increase in height of shoots (Table 2).

Escalona et al. (1999) reported a positive correlation between acclimatization survival and shoot size in pineapple. Increased fresh mass per shoot reduces losses in the acclimatization phase, which is considered the most critical

Table 1. Effect of culture medium (MSB only or MSB supplemented with $\mathrm{GA}_{3}(10 \mu \mathrm{M})$ ) on the regeneration rate (mean \pm standard deviation) of pineapple shoots in different immersion systems (temporary or permanent)

\begin{tabular}{lcc}
\hline \multirow{2}{*}{ Culture medium } & \multicolumn{2}{c}{ Culture system } \\
\cline { 2 - 3 } & PIS & TIS \\
\hline MSB $+\mathrm{GA}_{3}(10 \mu \mathrm{M})$ & $8.5 \pm 8.6 \mathrm{~B} \mathrm{~b}$ & $11.0 \pm 3.2 \mathrm{~A} \mathrm{a}$ \\
$\mathrm{MSB}$ & $13.1 \pm 16.9 \mathrm{~A} \mathrm{a}$ & $9.5 \pm 6.1 \mathrm{~A} \mathrm{~b}$ \\
\hline
\end{tabular}

Means followed by different letters, uppercase in column and lowercase in line, are different according to SNK test at $95 \%$ confidence. PIS: Permanent immersion system; TIS: Temporary immersion system.
Table 2. Effect of the shoot height class $(\mathrm{cm})$ on fresh mass per pineapple shoot

\begin{tabular}{lc}
\hline Class of shoot height $(\mathrm{cm})$ & Fresh mass per shoot $\left(\mathrm{g} \mathrm{shoot}^{-1}\right)$ \\
\hline$>7$ & $0.3385 \mathrm{~A}$ \\
$6-7$ & $0.2209 \mathrm{~B}$ \\
$5-6$ & $0.1940 \mathrm{~B}$ \\
$4-5$ & $0.1365 \mathrm{C}$ \\
$3-4$ & $0.0877 \mathrm{D}$ \\
$2-3$ & $0.0548 \mathrm{E}$ \\
\hline
\end{tabular}

Means followed by different letters vary according to SNK test at $95 \%$ confidence.

phase of the micropropagation process (Steinmacher et al. 2007). In the present work, MSB free of $\mathrm{GA}_{3}$ produced heavier shoots, while the shoots produced in MSB supplemented with $\mathrm{GA}_{3}$ were higher, but showed thinner stems, longer internodes and more elongated and thin leaves (Figure 4). It was also observed that shoots developed in PIS were more compact than those developed in TIS-TF, but this morphological difference was less marked than that observed in response to $\mathrm{GA}_{3}$.

\section{Acclimatization phase}

In the acclimatization phase, shoot survival showed no significant difference in response to the tested treatments $(\mathrm{p}>0.05)$, and all treatments resulted in a survival rate higher than $95 \%$. Similar survival rates for pineapple acclimatization were previously reported by Guerra et al. (1999), Sripaoraya et al. (2003), Amin et al. (2005), and Scherer et al. (2013).
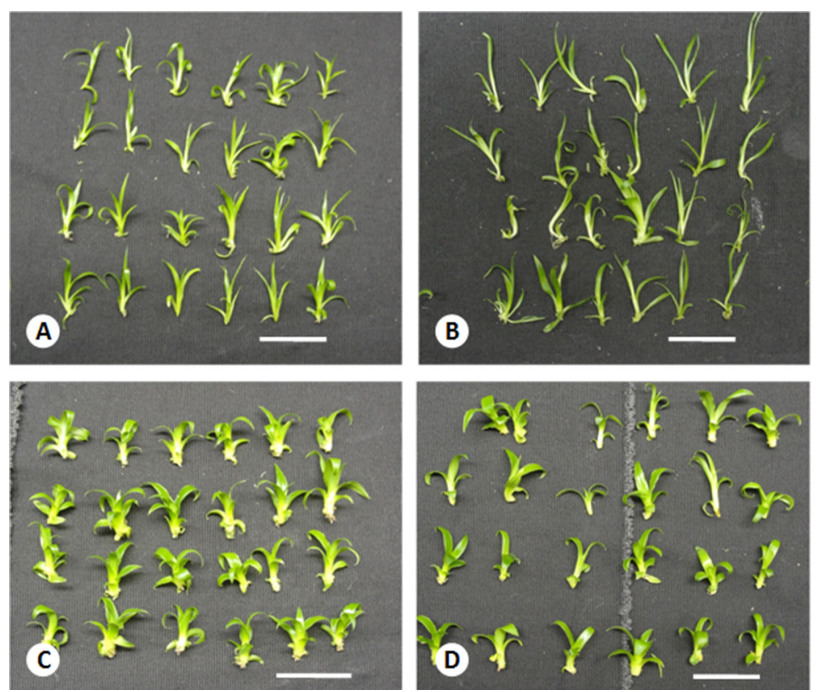

Figure 4. Pineapple shoots ( 3 to $4 \mathrm{~cm}$ ) micropropagated in temporary immersion system based on twin-flasks (TIS-TF) and in permanent immersion system (PIS) containing MSB culture medium supplemented, or not, with $\mathrm{GA}_{3}$ at $10 \mu \mathrm{M}$. Bar $=4 \mathrm{~cm}$. A - Shoots developed in PIS containing MSB and GA . B - Shoots developed in TIS-TF containing MSB and GA .

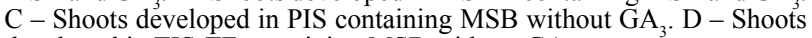
developed in TIS-TF containing MSB without $\mathrm{GA}_{3}$. 
Shoots developed in MSB free of $\mathrm{GA}_{3}$ showed enhanced vigor after acclimatization (data not shown), indicating consistency between plantlet vigor during acclimatization and FM per shoot during in vitro shoot growth.

Following the study, the newly established protocol was tested successfully in a biofactory system for mass production of plantlets, using adapted sterile plastic bottles (5 L) to make the twin-flasks of TIS-TF (Figure $1 \mathrm{G}, \mathrm{H}$ and I). Nowadays, Brazilian biofactories are widely employing this cost-effective TIS-TF system, mainly to produce sugarcane plantlets. Our observations indicate that such system could also be efficiently applied to pineapple mass propagation. Besides mass production of plantlets in biofactories, the high production of plantlets can also assist the genetic improvement of pineapple. For example, the maintenance of germplasm banks or progenies in this micropropagation system may allow for fast and large scale regeneration of target genotypes. Furthermore, the large scale production of micropropagated plantlets, coupled with the induction or selection of mutation can be employed for the generation of new genotypes of interest.

\section{CONCLUSIONS}

In summary, the results of the present study show that the combination of temporary immersion system based on twin flasks and MSB culture medium free of $\mathrm{GA}_{3}$ resulted in high regenerative efficiency, synchronic and homogenous development of shoots, as well as an enhanced shoot vigor and performance in the acclimatization phase. Additionally TIS-TF provided less handling and labor, and the MSB free of $\mathrm{GA}_{3}$ provided lower cost of culture medium. Taken together, those features contribute for i) a reduction in the production costs of pineapple plantlets, and ii) expressive improvements in the pineapple micropropagation protocols so far published.

\section{ACKNOWLEDGEMENTS}

The authors thank CAPES, CNPq and FAPESC for fellowship, research grants, and financial support for this study.

\section{Efeitos do sistema de imersão e do ácido giberélico no crescimento de microbrotos e na aclimatização de abacaxizeiro}

Resumo - Protocolos de micropropagação de plantas possibilitam a produção de mudas isentas de pragas e doenças. No presente trabalho, objetivando a otimização da micropropagação do abacaxizeiro [Ananas comosus (L.) Merril], foram avaliados três fatores: 1) sistema de imersão (temporária por frascos duplos em erlenmeyers de 2 L ou permanente); 2) meio de cultura (suplementado, ou não, com Ácido Giberélico); 3) classe de altura de brotos. Os efeitos na taxa de regeneração (número de novos brotos para cada 1 $g$ de massa fresca (MF) de microbrotos inoculada), na MF por broto, e na sobrevivência dos brotos foram avaliados. Interações significativas $(p<0,05)$ foram observadas na taxa de regeneração, e efeitos simples $(p<0,05)$ foram detectados na MF por broto. Todos os tratamentos resultaram em sobrevivência de mudas superior a 95\% na aclimatização. Concluiu-se que a combinação do sistema de imersão temporária em frascos duplos e o meio de cultura isento de $A G_{3}$ resultou na otimização do protocolo regenerativo. Esta combinação também demonstrou resposta positiva em um sistema de imersão temporária usual em biofábricas, que utiliza frascos duplos em garrafas PET de $5 L$.

Palavras-chave: Micropropagação, taxa de regeneração, biofábricas.

\section{REFERENCES}

Amin MN, Rahman MM, Rahman KW, Ahmed R, Hossain MS and Ahmed MB (2005) Large scale plant regeneration in vitro from leaf derived callus cultures of pineapple [Ananas comosus (L.) Merr. cv. Giant Kew]. International Journal of Botany 1: 128-132.

Be LV and Debergh PC (2006) Potential low cost micro-propagation of pineapple (Ananas comosus). South African Journal of Botany 72: 191-194.

Box GEP and Cox DR (1964) An analysis of transformations. Journal of the Royal Statistical Society: Series B 39: 211-252.

Clement CR, Cristo-Araújo M, D’Eeckenbrugge GC, Pereira AA and Picanço-Rodrigues D (2010) Origin and domestication of native amazonian crops. Diversity 2: 72-106.

Dal Vesco LL, Pinto AA, Zaffari GR, Nodari RO, Reis MS and Guerra MP
(2001) Improving pineapple micropropagation protocol trough explant size and medium composition manipulation. Fruits 56: 143-154.

Dal Vesco LL and Guerra MP (2010) In vitro morphogenesis and adventitious shoot mass regeneration of Vriesea reitzii from nodule cultures. Scientia Horticulturae 125: 748-755.

Dal Vesco LL, Stefenon VM, Welter LJ, Scherer RF and Guerra MP (2011) Induction and scale-up of Bilbergia zebrina nodule cluster cultures: implications for mass propagation, improvement and conservation. Scientia Horticulturae 128: 515-522.

Dronne S, Jullien F, Caissard J-C and Faure O (1999) A simple and efficient method for in vitro shoot regeneration from leaves of lavandin (Lavandula $\mathrm{x}$ intermedia Emeric ex Loiseleur). Plant Cell Reports 18: 429-433.

Escalona M, Lorenzo JC, Gonzalez BL, Daquinta M, Gonzalez JL, 
Effects of immersion system and gibberellic acid on the growth and acclimatization of micropropagated pineapple

Desjardins Y and Borroto CG (1999) Pineapple (Ananas comosus (L.) Merr.) micropropagation in temporary immersion systems. Plant Cell Reports 18: 743-748.

Etienne H, Lartaud M, Michaux-Ferriere N, Carron MP, Berthouly M and Teisson C (1997) Improvement of somatic embryogenesis in Hevea brasiliensis (Mull. Arg.) using the temporary immersion technique. In Vitro Cellular \& Developmental Biology - Plant 33: 81-87.

Etienne H and Berthouly M (2002) Temporary immersion systems in plant micropropagation. Plant Cell, Tissue and Organ Culture 69: $215-231$

FAOSTAT, FAO statistical databases, pineapple data (2011) Food and Agriculture Organization of the United Nations, Rome, Italy. Available at <http:// http://faostat.fao.org/site/567/DesktopDefault. aspx? PageID=567\#ancor $>$. Accessed on Dec 29, 2012.

Feuser S, Meler K, Daquinta M and Guerra MP (2003) Genotypic fidelity of micropropagated pineapple (Ananas comosus) plantlets assessed by isoenzyme and RAPD markers. Plant Cell, Tissue and Organ Culture 72: 221-227.

Girek Z, Prodanovic S, Zdravkovic J, Zivanovic T, Ugrinovic M and Zdravkovic M (2013) The effect of growth regulators on sex expression in Melon (Cucumis melo L.). Crop Breeding and Applied Biotechnology 13: 165-171.

Guerra MP and Dal Vesco LL (2010) Strategies for the micropropagation of bromeliads. In Jain SM and Ochatt SJ (Eds) Protocols for in vitro propagation of ornamental plants: methods in molecular biology. Humana Press-Springer, New York, p. 47-66.

Guerra MP, Dal Vesco LL, Pescador R, Schuelter AR and Nodari RO (1999) Estabelecimento de um protocolo regenerativo para a micropropagação do abacaxizeiro. Pesquisa Agropecuária Brasileira 34: 1557-1563.

Hanhineva K, Kokko H and Kärenlampi S (2005) Shoot regeneration from leaf explants of five strawberry (Fragaria $\times$ ananassa) cultivars in temporary immersion bioreactor system. In Vitro Cellular \& Developmental Biology - Plant 41: 826-831

Hedden P and Thomas GS (2012) Gibberellin biosynthesis and its regulation. Biochemical Journal 444: 11-25.

Lorenzo JC, Gonzalez BL, Escalona M, Teisson C, Espinosa P and Borroto C (1998) Sugarcane shoot formation in an improved temporary immersion system. Plant Cell, Tissue and Organ Culture 54: 197-200

McAlister B, Finnie J, Watt MP and Blakeway F (2005) Use of the temporary immersion bioreactor system (RITA) for production of commercial Eucalyptus clones in Mondi Forest (SA). Plant Cell, Tissue and Organ Culture 81: 347-358.

Morel GM and Wetmore RH (1951) Tissue culture of monocotyledons. American Journal of Botany 38: 138-140.

Murashige T and Skoog F (1962) A revised medium for rapid growth and biossays with tobacco tissue cultures. Physiologia Plantarum 15: 473-497.
Niemenak N, Saare-Surminski K, Rohsius C, Ndoumou DO and Lieberei R (2008) Regeneration of somatic embryos in Theobroma cacao L. in temporary immersion bioreactors and analyses of free amino acids in different tissue. Plant Cell Reports 27: 667-676.

Oliveira ML, Xavier A, Penchel RM, Santos AF (2011) Multiplicação in vitro de Eucalyptus grandis x E. urophylla cultivado em meio semissólido e em biorreator de imersão temporária. Scientia Forestalis 39: 309-315.

Peña-Ramíres YJ, Juárez-Gómez J, Gómez-López L, Jerónimo-Pérez JL, García-Sheseña I, González-Rodríguez A and Robert ML (2010) Multiple adventitious shoot formation in spanish red cedar (Cedrella odorata L.) cultured in vitro using juvenile and mature tissues: an improved micropropagation protocol for a highly valuable tropical species. In Vitro Cellular \& Developmental Biology - Plant 46: 149-160.

Quiala E, Barbón R, Jiménez E, de Feria M, Chávez M, Capote A and Pérez N (2006) Biomass production of Cymbopogon citratus (D.C.) Stapf., a medicinal plant, in temporary immersion systems. In Vitro Cellular \& Developmental Biology - Plant 42: 298-300.

Rastogi A, Siddiqui A, Mishra BK, Srivastava M, Pandey R, Misra P, Singh M and Shukla S (2013) Effect of auxin and gibberellic acid on growth and yield components of linseed (Linum usitatissimum L.). Crop Breeding and Applied Biotechnology 13: 136-143.

Rech Filho A, Dal Vesco LL, Nodari RO, Lischka RW, Müller CV and Guerra MP (2005) Tissue culture for the conservation and mass propagation of Vriesea reitzii Leme and Costa, a bromeliad threatened of extinction from the Brazilian Atlantic Forest. Biodiversity and Conservation 14: 1799-1808.

Reinhardt A and Rodriguez LV (2009) Industrial processing of pineapple - trends and perspectives. Acta Hort (ISHS) 822: 323-328.

Scherer RF, Garcia AC, Fraga HPF, Dal Vesco LL, Steinmacher DA and Guerra MP (2013) Nodule cluster cultures and temporary immersion bioreactors as a high performance micropropagation strategy in pineapple (Ananas comosus var. comosus). Scientia Horticulturae 151: $38-45$.

Sripaoraya S, Marchant R, Power JB and Davey MR (2003) Plant regeneration by somatic embryogenesis and organogenesis in commercial pineapple (Ananas comosus L.). In Vitro Cellular \& Developmental Biology - Plant 39: 450-454.

Steinmacher DA, Cangahuala-Inocente GC, Clement CR and Guerra MP (2007) Somatic embryogenesis from peach palm zygotic embryos. In Vitro Cellular \& Developmental Biology - Plant 43: 124-132.

Steinmacher DA, Guerra MP, Saare-Surminski K and Lieberei R (2011) Temporary immersion system improves in vitro regeneration of peach palm through secondary somatic embryogenesis. Annals of Botany 108: $1463-1475$.

Teixeira J, Cruz ARR, Ferreira FR and Cabral JR (2001) Biotecnologia aplicada à produção de mudas: produção de mudas micropropagadas de abacaxi. Biotecnologia Ciência \& Desenvolvimento 3: 42-47. 